\title{
Screening of Central and South American plant extracts for antimycobacterial activity by the Alamar Blue test
}

\author{
Suzana G. Leitão ${ }^{1 *}$, Oscar Castro², Eduardo N. Fonseca ${ }^{1}$, Lisieux S. Julião ${ }^{3}$, Eliana S. \\ Tavares $^{3}$, Rodrigo R.T. Leo ${ }^{3}$, Ricardo C. Vieira ${ }^{3}$, Danilo R. Oliveira ${ }^{4}$, Gilda G. Leitão ${ }^{4}$, Virginia \\ Martino5 $^{5}$, Valeria Sulsen, ${ }^{5}$ Ymira A.G. Barbosa ${ }^{1}$, Diva P.G. Pinheiro ${ }^{1}$, Pedro E. Almeida da \\ Silva $^{6}$, Dulcineia F. Teixeira ${ }^{7}$, Ivan N. Junior ${ }^{8}$, Maria Cristina S. Lourenço ${ }^{8}$
}

${ }^{1}$ Departamento de Produtos Naturais e Alimentos, Faculdade de Farmácia, Universidade Federal do Rio de Janeiro, Ilha do Fundão, 21941-590, Rio de Janeiro, RJ, Brazil,

${ }^{2}$ Departamento de Química, Universidad Nacional, Heredia, Costa Rica,

${ }^{3}$ Departamento de Botânica, Instituto de Biologia, Universidade Federal do Rio de Janeiro, Ilha do Fundão, 21951-590, Rio de Janeiro, RJ, Brazil,

${ }^{4}$ Núcleo de Pesquisas de Produtos Naturais, Universidade Federal do Rio de Janeiro, Ilha do Fundão, 21941-590, Rio de Janeiro, RJ, Brazil,

${ }^{5}$ Cátedra de Farmacognosia, Instituto de Química y Metabolismo del Fármaco (UBA - CONICET), Facultad de Farmacia y Bioquímica, Universidad de Buenos Aires, Buenos Aires, Argentina, ${ }^{6}$ Laboratório de Micobacterias, Departamento de Patologia, Fundação Universidade Federal do do Rio Grande, Rio Grande, 96200-190, Rio Grande do Sul, Brazil,

${ }^{7}$ Farmanguinhos, Fiocruz, Rua Sizenando Nabuco 100, Manguinhos, 21041-250, Rio de Janeiro, RJ, Brasil, ${ }^{8}$ Instituto de Pesquisa Clínica Evandro Chagas, Serviço de Bacteriologia, Setor de Testagem de Drogas, Fiocruz, 21045-900, Rio de Janeiro, RJ, Brazil

S. G. Leitão wishes to dedicate this work in memory of Prof. Nikolai Sharapin who kindly introduced the author to the CYTED Program

\begin{abstract}
RESUMO: "Triagem de extratos de plantas das Américas Central e do Sul para atividade antimicobacteriana pelo teste do Alamar Blue". Quarenta e oito extratos brutos etanólicos e frações (em hexano, diclorometano, acetato de etila e n-butanol) de dez plantas brasileiras pertencentes às famílias Leguminosae, Monimiaceae e Verbenaceae; uma da Costa Rica (Verbenaceae) e uma da Argentina (Verbenaceae) foram ensaiados para verificação da atividade anti-micobacteriana contra Mycobacterium tuberculosis (ATCC-27294 $\mathrm{H}_{37} \mathrm{Rv}$ ), pelo teste do Alamar Blue, a uma concentração fixa de $100 \mu \mathrm{g} / \mathrm{mL}$. Dentre os quarenta e oito extratos e frações estudados, sete mostraram-se ativos na concentração ensaiada - frações em hexano e diclorometano de folhas de Lantana trifolia, extrato em metanol:água, 1:1 de cascas de Vitex cooperi, frações em hexano e diclorometano de folhas de Lippia lacunosa e de Lippia rotundifolia, sendo que todas essas plantas pertencem à família Verbenaceae.
\end{abstract}

Unitermos: Mycobacterium tuberculosis, Lantana trifolia, Vitex cooperi, Lippia lacunosa, Lippia rotundifolia, atividade antimicobacteriana, 20-hidroxi-ecdisona.

\begin{abstract}
Forty eight ethanolic crude extracts and fractions (hexane, dichloromethane, ethyl acetate and n-butanol) from ten Brazilian plants (Leguminosae, Monimiaceae and Verbenaceae), 1 from Costa Rica (Verbenaceae) and 1 from Argentina (Verbenaceae) were screened for antimycobacterium activity against Mycobacterium tuberculosis (ATCC-27294 $\mathrm{H}_{37} \mathrm{Rv}$ ), by the Alamar Blue test, at a fixed concentration of $100 \mu \mathrm{g} / \mathrm{mL}$. Out of the forty eight, seven were active at this concentration, corresponding to Lantana trifolia (hexane and dichloromethane extracts from leaves), Vitex cooperi (methanol:water, 1:1 extract from barks), Lippia lacunosa (hexane and dichloromethane extracts from leaves) and Lippia rotundifolia (hexane and dichloromethane extracts from leaves), all from the Verbenaceae family.
\end{abstract}

Keywords: Mycobacterium tuberculosis, Lantana trifolia, Vitex cooperi, Lippia lacunosa, Lippia rotundifolia, antimycobacterial activity, 20-hydroxyecdysone. 


\section{INTRODUCTION}

Tuberculosis (TB) is a systemic disease caused by Mycobacterium tuberculosis, the alcohol-acid resistant bacillus, discovered by Robert Koch more than 120 years ago. Despite the discovery of very effective drugs against it more then 40 years ago, it still remains a serious health problem in many regions of the world, specially in developing nations (Lall; Meyer, 1999). Currently, almost one third of the world population is infected with $M$. tuberculosis, and each year 2-3 million people die from it (Newton et al., 2002). It is estimated that between the years 2000 and 2020 nearly one billion people will be newly infected, 20 million will develop TB and 35 million will die from the disease (WHO, 2000). It is estimated that in Latin America approximately 600.000 new cases of tuberculosis occur per year. Brazil, with c.a. 129.000 new cases per year, ranks the $13^{\circ}$ position within other 22 countries with high-burden of TB incidence. The estimated incidence of TB in Costa Rica and Brazil is 15 and 62/100.000 respectively (WHO,2005). The emergence of multidrug resistant strains (MDR) of M. tuberculosis as well as human immunodeficiency virus (HIV) infection have greatly amplified the incidence of TB, reaffirming tuberculosis as a primary public health threat. In the past 5 years several reports and review articles appeared in the literature about medicinal plants and natural products with anti-mycobacterium activity (Okunade et al., 2004; Copp, 2003; Newton et al., 2002; Cantrell et al., 2001). Over 350 natural products, mainly from plant species have been assessed for their antimycobacterial activities (Newton et al., 2002). A number have demonstrated significant in vitro antimycobacterial activity and active plant-derived compounds belonging to various chemical classes have been isolated (Newton et al., 2002). In recent years, a notable number of natural product-derived agents has been discovered by employing screening approaches involving cellular or biochemical targets in their assay design (Shu, 1998). In this way, we initiated a screening for anti-mycobacterium activity of some plant extracts against Mycobacterium tuberculosis (ATCC-27294 $\mathrm{H}_{37} \mathrm{Rv}$ ), by the Alamar Blue test.

\section{MATERIAL AND METHODS}

\section{Plant material}

Plant species, collection sites as well as voucher specimen numbers are described in Table 1.

\section{Plant extracts}

Plants were extracted as follows, or otherwise, as described in Exceptions. Dried and pulverized plant materials were exhaustively extracted with ethanol and the extract was concentrated under reduced pressure to afford a brown syrup. This residue was suspended in water and extracted successively with organic solvents: hexane, dichloromethane, ethyl acetate and $n$-butanol, in this order.

\section{Exceptions}

Lippia integrifolia - Organic extracts - Air dried plant material $(10 \mathrm{~g})$ was ground and extracted by soaking in dichloromethane $(100 \mathrm{ml})$ at room temperature for 24 $\mathrm{h}$ and then filtered. The process was repeated 3 times. The filtrates were combined and taken to dryness under vacuum. The plant material was then extracted with methanol under the same conditions. Aqueous extract Dried ground plant material $(50 \mathrm{~g})$ was extracted with hot water $(500 \mathrm{ml})$ by maceration at room temperature for 20 minutes. The extract was filtered and freeze-dried. Vitex cooperi $-90 \mathrm{~g}$ of bark and wood were separately extracted twice with ethanol-water (7:3) for $24 \mathrm{~h}$. The filtrates were combined and taken to dryness under vacuum.

\section{Fractionation of Vitex cooperi bark methanol-water extract}

The methanol-water extract $(700 \mathrm{mg})$ from the bark of $V$. cooperi was chromatographed on silica gel eluted with mixtures of hexane, dichloromethane, ethyl acetate and methanol, to afford 21 fractions. Fractions 7 $(24 \mathrm{mg})$ and $8(17 \mathrm{mg})$ eluted with dichloromethane; 10 $(13 \mathrm{mg})$ and $12(10 \mathrm{mg})$ eluted with dichloromethane ethyl acetate (1:1); and $14(15 \mathrm{mg})$ and $15(10 \mathrm{mg})$, eluted with ethyl acetate, were active by the Alamar Blue test. 20 -Hydroxyecdysone was detected on fraction 17 by TCL and co-TLC with an authentic sample isolated from V. cymosa bark (Santos et al., 2001). Due to the limited amount of the remaining active fractions (c.a. $5 \mathrm{mg}$ were used for the Alamar Blue test), GC-MS analysis was performed in order to identify possible active substances. In fractions 7 and 8 the phytosterols sitosterol and stigmasterol were identified.

\section{GC-MS analyses}

The GC/MS system used was an Agilent 5973 MSD coupled to an Agilent $6890 \mathrm{~N}$ gas chromatograph equipped with an automatic injector (5683). Conditions: helium as carrier gas ( $\left.1 \mathrm{ml} . \mathrm{min}^{-1}\right)$; fused capillary column: HP-5 (5\% phenylmethyl silicone); injector temperature: $270^{\circ} \mathrm{C}$, and the column oven program was $70^{\circ}$ to $290^{\circ} \mathrm{C}$ at $4^{\circ} \mathrm{C} \min ^{-1}$. Detector was operated at $280^{\circ} \mathrm{C}$. Injection volume, $1 \mu \mathrm{l}$ (split 1:10). Data acquisition was obtained with a HP CHEMISTATION Acquisition Software. Substances were identified by comparison of their mass spectra with those in a spectral database (Wiley $7 \mathrm{~N}$ ) and with literature (Budzikiewicz, 1974).

\section{Alamar Blue Test}


Table 1. Susceptibility of Mycobacterium tuberculosis $\mathrm{H}_{37} \mathrm{Rv}$ to the different Verbenaceae, Leguminosae and Monimiaceae plant extracts, as well as their collection sites and voucher specimen numbers.

\begin{tabular}{|c|c|c|c|c|c|c|}
\hline Plant species & Family & $\begin{array}{l}\text { Plant } \\
\text { Part } \\
\text { Used }\end{array}$ & Extract & $\begin{array}{c}\text { Suscepti bility } \\
\text { of } \mathrm{H}_{3} \mathrm{Rv} \\
\text { (MIC)* }\end{array}$ & $\begin{array}{c}\text { Plant collection } \\
\text { site }\end{array}$ & $\begin{array}{l}\text { Voucher } \\
\text { specimen } \\
\text { number }\end{array}$ \\
\hline \multirow[t]{2}{*}{$\begin{array}{l}\text { Bauhinia } \\
\text { microstachya var. } \\
\text { massambabensis }\end{array}$} & Leguminosae & $\mathrm{L}$ & $\mathrm{E}$ & $\mathrm{R}$ & $\begin{array}{l}\text { B, Rio de Janeiro, } \\
\text { Marica restinga }\end{array}$ & RFA 30813 \\
\hline & & $\begin{array}{l}\text { L } \\
\text { L } \\
\text { L } \\
\text { L }\end{array}$ & $\begin{array}{l}\mathrm{H} \\
\mathrm{D} \\
\mathrm{A} \\
\mathrm{B}\end{array}$ & $\begin{array}{l}\mathrm{R} \\
\mathrm{R} \\
\mathrm{R} \\
\mathrm{R}\end{array}$ & & \\
\hline \multirow[t]{2}{*}{$\begin{array}{l}\text { Bauhinia } \\
\text { microstachya var. } \\
\text { microstac hya }\end{array}$} & Leguminosae & $\mathrm{L}$ & E & $\mathrm{R}$ & $\begin{array}{l}\text { B, Rio de Janeiro, } \\
\text { Atlantic Forest }\end{array}$ & RFA 28253 \\
\hline & & $\begin{array}{l}\text { L } \\
\text { L } \\
\text { L } \\
\text { L }\end{array}$ & $\begin{array}{l}\text { H } \\
\text { D } \\
\text { A } \\
\text { B }\end{array}$ & $\begin{array}{l}\mathrm{R} \\
\mathrm{R} \\
\mathrm{R} \\
\mathrm{R}\end{array}$ & & \\
\hline \multirow{3}{*}{$\begin{array}{l}\text { Lippia } \\
\text { origanoides } \\
\text { Lippia alba forma } \\
\text { intermedia }\end{array}$} & Verbenaceae & $\mathrm{L}$ & E & $\mathrm{R}$ & $\begin{array}{l}\text { B, Pará State, } \\
\text { Oriximiná }\end{array}$ & $\begin{array}{l}\text { CESJ } \\
39532\end{array}$ \\
\hline & Verbenaceae & $\mathrm{L}$ & $\mathrm{E}$ & $\mathrm{R}$ & $\begin{array}{l}\text { B, Pará State, } \\
\text { Oriximin á }\end{array}$ & $\begin{array}{l}\text { CESJ } \\
39530\end{array}$ \\
\hline & & $\begin{array}{l}\text { L } \\
\text { L } \\
\text { L } \\
\text { L }\end{array}$ & $\begin{array}{l}\mathrm{H} \\
\mathrm{D} \\
\mathrm{A} \\
\mathrm{B}\end{array}$ & $\begin{array}{l}\mathrm{R} \\
\mathrm{R} \\
\mathrm{R} \\
\mathrm{R}\end{array}$ & & \\
\hline Lantana trifolia & Verbenaceae & $\begin{array}{l}\text { S } \\
\text { S } \\
\text { S } \\
\text { S } \\
\text { S } \\
\text { L } \\
\text { L } \\
\text { L } \\
\text { L } \\
\text { L }\end{array}$ & $\begin{array}{l}\text { E } \\
\text { H } \\
\text { D } \\
\text { A } \\
\text { B } \\
\text { E } \\
\text { H } \\
\text { D } \\
\text { A } \\
\text { B }\end{array}$ & $\begin{array}{c}\mathrm{R} \\
\mathrm{R} \\
\mathrm{R} \\
\mathrm{R} \\
\mathrm{R} \\
\mathrm{R} \\
\mathrm{S}(80) \\
\mathrm{S}(80) \\
\mathrm{R} \\
\mathrm{R}\end{array}$ & $\mathbf{B}$, Rio de Janeiro & RFA 30801 \\
\hline $\begin{array}{l}\text { Hennecartia } \\
\text { omphalandra }\end{array}$ & Monimiaceae & $\mathrm{L}$ & $\mathrm{E}$ & $\mathrm{R}$ & $\begin{array}{l}\text { B, Londrina, } \\
\text { Paraná State }\end{array}$ & RFA 30840 \\
\hline Vitex cooperi & Verbenaceae & B & $\mathrm{E}$ & $\mathrm{S}(80)$ & $\begin{array}{l}\text { San Carlos, } \\
\text { Alajuela, CO }\end{array}$ & $¥$ \\
\hline \multirow[t]{2}{*}{ Vitex cymosa } & Verbenaceae & $\mathrm{F}$ & E & $\mathrm{R}$ & $\begin{array}{l}\text { B, Corumbá, } \\
\text { Mato Grosso do } \\
\text { Sul State }\end{array}$ & $\begin{array}{c}\text { CESJ } \\
11.711\end{array}$ \\
\hline & & $\mathrm{F}$ & $\mathrm{H}$ & $\mathrm{R}$ & & \\
\hline \multirow[t]{2}{*}{ Vitex polygama } & Verbenac eae & $\mathrm{L}$ & $\mathrm{H}$ & $\mathrm{R}$ & $\begin{array}{c}\text { B, Rio de Janeiro } \\
\text { State, } \\
\text { Marica restinga }\end{array}$ & $\begin{array}{c}\text { CESJ } \\
45.217\end{array}$ \\
\hline & & $\begin{array}{l}\mathrm{L} \\
\mathrm{L}\end{array}$ & $\begin{array}{l}\mathrm{D} \\
\mathrm{A}\end{array}$ & $\begin{array}{l}\mathrm{R} \\
\mathrm{R}\end{array}$ & & \\
\hline Lippia integrifolia & Verbenaceae & A & WI & $\mathrm{R}$ & $\begin{array}{c}\text { A, Tafí del Valle, } \\
\text { Tucumán } \\
\text { Province, }\end{array}$ & Slanis 178 \# \\
\hline
\end{tabular}




\begin{tabular}{|c|c|c|c|c|c|c|}
\hline \multirow[b]{3}{*}{ Lippia lacunosa } & \multirow[b]{3}{*}{ Verbenaceae } & \multirow{3}{*}{$\begin{array}{l}\text { A } \\
\text { A } \\
\text { L }\end{array}$} & \multirow{3}{*}{$\begin{array}{l}\mathrm{M} \\
\mathrm{D} \\
\mathrm{E}\end{array}$} & \multirow{2}{*}{$\begin{array}{l}\mathrm{R} \\
\mathrm{R}\end{array}$} & \multirow[b]{3}{*}{$\begin{array}{c}\text { B, Juiz de Fora } \\
\text { (MG) }\end{array}$} & \multirow[b]{3}{*}{$\begin{array}{r}\text { CESJ } \\
41.691\end{array}$} \\
\hline & & & & & & \\
\hline & & & & $\mathrm{R}$ & & \\
\hline \multirow{10}{*}{$\begin{array}{l}\text { Lippia } \\
\text { rotundifolia }\end{array}$} & \multirow{10}{*}{ Verbenaceae } & $\mathrm{L}$ & $\mathrm{H}$ & $\mathrm{S}(>100)$ & \multirow{10}{*}{$\begin{array}{c}\text { B, Juiz de Fora } \\
\text { (MG) }\end{array}$} & \multirow{10}{*}{$\begin{array}{c}\text { CESJ } \\
31.376\end{array}$} \\
\hline & & $\mathrm{L}$ & $\mathrm{D}$ & S (25) & & \\
\hline & & $\mathrm{L}$ & A & $\mathrm{R}$ & & \\
\hline & & $\mathrm{L}$ & $\mathrm{B}$ & $\mathrm{R}$ & & \\
\hline & & $\mathrm{L}$ & $\mathrm{E}$ & $\mathrm{R}$ & & \\
\hline & & & & & & \\
\hline & & $\mathrm{L}$ & $\mathrm{H}$ & $\mathrm{S}(50)$ & & \\
\hline & & $\mathrm{L}$ & $\mathrm{D}$ & S (25) & & \\
\hline & & $\mathrm{L}$ & $\mathrm{A}$ & $\mathrm{R}$ & & \\
\hline & & $\mathrm{L}$ & $\mathrm{B}$ & $\mathrm{R}$ & & \\
\hline
\end{tabular}

Used part: L, leaves; S, stems; B, barks; F, fruits; W, woods; R, roots; A, aerial parts.

Extract: E, ethanol; H, hexane; D, dichloromethane; A, ethyl acetate; B, $n$-butanol; WI, water infusion; M, methanol.

$* \mathbf{R}$, resistant; $\mathbf{S}$, sensitive; MIC values in $\mu \mathrm{g} / \mathrm{ml}$.

Plant collection site: A, Argentina; B, Brazil; CO, Costa Rica.

${ }^{¥}$ Identification was accomplished by comparison with an authentic sample deposited in Universidad Nacional Herbarium and confirmed by the botanist Luis J. Poveda.

\# Voucher specimen deposited at the Herbarium of Fundación Miguel Lillo.

MABA (Microplate Alamar Blue Assay) susceptibility testing was performed according to the method described by Franzblau et al. (1998). Final concentration of plant extract was $100 \mu \mathrm{g} / \mathrm{ml}$. Media plus bacteria with and without rifampicin were used as controls. The strain $\mathrm{H}_{37} \mathrm{Rv}$ (ATCC - 27294) was used for all methodologies. The BACTEC ${ }^{\circledR}$ (Becton \& Dickinson) radiometric test was used as reference to confirm antimycobacterium activity of plants extracts. Samples were simultaneously screened by both microbiology laboratories.

\section{RESULTS}

A total of 48 ethanolic crude extracts and fractions (hexane, dichloromethane, ethyl acetate and n-butanol) from 10 Brazilian plants (Leguminosae, Monimiaceae and Verbenaceae), 1 from Costa Rica (Verbenaceae) and 1 from Argentina (Verbenaceae) were assayed at a fixed concentration of $100 \mu \mathrm{g} / \mathrm{mL}$ - Table 1. Out of the assayed extracts, seven, belonging to the Verbenaceae family presented antimycobacterial activity at this concentration. All extracts were simultaneously assayed by the Alamar Blue Test at the two microbiology laboratories (Fiocruz, Rio de Janeiro and FURG, Rio Grande do Sul), in order to assure an interlaboratorial control.

\section{DISCUSSION}

Analysis of the results reported in Table 1 drew our attention to the fact that Lantana trifolia, Lippia lacunosa and Lippia rotundifolia crude ethanolic extracts were inactive, whereas the hexane and dichloromethane fractions obtained from them (except for those from $L$. trifolia stems) were active at the same final concentration of the original extracts. When the search for biological activity is not based on ethno-pharmacological information, a question often arises which is what kind of extract is the best one to be prepared. In the specific case of these three plant extracts we could observe that the prepurification step of the crude ethanolic extract by liquidliquid partition played a crucial role in the assessment of the antimycobacterial activity. Literature search (Van Puyvelde et al., 1994; Boily; Van Puyvelde, 1986) showed that a crude ethanolic extract of Lantana trifolia collected in Rwanda, and prepared in the same way as ours had been previously assayed for antimycobacterial activity - M. smegmatis (Boily; Van Puyvelde, 1986) and clinical strains of $M$. tuberculosis (Van Puyvelde et al., 1994), and similarly, no positive activity was found, corroborating with our results. However, the report on the antimycobacterial activity of another species from the genus Lantana - L. hispida (Jimenez-Arellanes et al. 2003), prompted us to investigate this activity on the Lantana trifolia fractions. The active hexane and dichloromethane fractions from the leaves of Lantana trifolia, Lippia lacunosa and Lippia rotundifolia are now being submitted to bioassay-guided fractionation to locate the active(s) substance(s). Here, we report the bioassay-guided fractionation of Vitex cooperi's methanol-water extract, in order to isolate their antimycobacterial substances. Fractionation by silica gel column chromatography of this extract led to the separation of 21 fractions, one of which containing ecdysteroids, which are common constituents of the barks of Vitex species (Santos et al., 2001; Suksamram; Sommechai, 1993). Comparative TLC and also co-TLC of this fraction with an authentic sample of 20-hydroxyecdysone, previously isolated in 
our laboratory from the barks of Vitex cymosa (Santos et al., 2001), showed the presence of this substance in Vitex cooperi's bark extract. Owing to the fact that the two extracts from $V$. cooperi (bark and wood) have very similar chromatographic profiles, with the exception of 20-hydroxyecdysone which is present only in the active one (bark), we decided to evaluate the susceptibility of M. tuberculosis to this substance. 20-hydroecdysone was assayed at $100 \mu \mathrm{g} / \mathrm{mL}$ but failed to demonstrate any activity against $M$. tuberculosis at this concentration. In this way, we searched for the antimycobacterium activity on the other fractions by the Alamar Blue test. Six fractions turned out to be active. Unfortunately, due to the limited amount of them (10 to $15 \mathrm{mg}$ ), further purification steps by traditional open column chromatography were unfeasible. In this way, GC-MS analysis was performed in order to tentatively identify possible active substances. In fractions 7 and 8 the phytosterols sitosterol and stigmasterol were identified by comparison of their mass spectra with those in a spectral database (Wiley $7 \mathrm{~N}$ ) and with those in the literature (Budzikiewicz, 1974). These sterols have already been identified as the antimycobacterial principles of the hexane fraction of Morinda citrifolia (Saludes et al., 2002), with MICs of $128 \mu \mathrm{g} / \mathrm{mL}$ (sitosterol) (Okunade et al., 2004) and $32 \mu \mathrm{g} / \mathrm{mL}$ (stigmasterol) (Okunade et al., 2004). Although the MIC reported in literature for sitosterol lies above $100 \mu \mathrm{g} / \mathrm{mL}$, the fact that fractions 7 and 8 are active at this concentration may be explained by the presence of stigmasterol (MIC $32 \mu \mathrm{g} / \mathrm{mL}$ ) in the mixture. Sitosterol has also been found in many active plant extracts against Mycobacterium tuberculosis such as Chamaedora tepejilote (Jimenez et al., 2005), Junellia tridens (Caldwell et al., 2000) and Euphorbia ebracteolata (Zhang et al., 1987), together with other antimycobacterium compounds. Also, in a clinical study (randomised placebo-controlled trial) of the efficacy of beta-sitosterol and its glucoside as adjuvants in the treatmentofpulmonarytuberculosissignificantlyimproved weight gain and higher lymphocyte and eosinophil counts in positive TB patients receiving sitosterols in addition to an efficacious antituberculosis regimen has been shown (Donald et al., 1998). Authors propose that sitosterols and their possible mode of action should be evaluated in larger numbers of tuberculosis patients and in diseases with a similar immunopathogenesis.

Therefore, we can suggest that the presence of these phytosterols in the bark extract of Vitex cooperi may account for the antimycobacterial activity of this plant.

\section{CONCLUSION}

The screening of 48 south and central America plant extracts for antimycobacterium activity led to the discovery of 7 active ones, all from the Verbenaceae family. With the exception of Vitex cooperi 's methanol: water extract, all the others were obtained by liquidliquid partition of their crude ethanolic extracts, showing that pre-purification steps played a crucial role in the assessment of the antimycobacterial activity. The results obtained also pointed out a trend of activity concentration towards the more lipophilic extracts (hexane and dichloromethane). In the case of the active polar methanol-water extract from V. cooperi, bioassayguided fractionation by column chromatography led to the identification of two phytosterols in the less polar (lipophilic) fractions of this extract, which may account for the antimycobacterium activity of this plant. These results are in agreement with recent reports that the cell wall of Mycobacterium tuberculosis has high permeability to hydrophobic compounds (Korycka-Machala et al., 2005).

The therapeutic arsenal to the treatment of tuberculosis is reduced; furthermore the treatment is long. This is a serious problem that has worsened in the last times because of the increase of TB cases with resistant Mycobacterium tuberculosis strains. Therefore, the search for new drugs from natural origin is urgent and extremely important to developing countries like Brazil and Costa Rica, which are the richest countries in terms of biodiversity.

\section{AKNOWLEDGEMENTS}

Collaborative work was performed under the auspices of the Iberoamerican Program for Science and Technology (CYTED), Project X.11:PIBATUB. S. G. Leitão is indebted to CNPq (Edital Universal n. 477060/2004-8) for financial support. Some of us are indebted to CAPES and CNPq for fellowships, and for UNICEF/UNDP/World Bank/WHO Special Program for Research and Training in Tropical Diseases (TDR).

\section{REFERENCES}

Boily Y, Van Puyvelde L 1986. Screening of medicinal-plants of Rwanda (central-Africa) for antimicrobial activity. J Ethnopharmacol 16: 1-13.

Budzikiewicz H 1974 Steroids. In: Waller GR, ed. Biochemical applications of mass spectrometry. New York: Wiley-Interscience. p.251-286.

Caldwell CG, Franzblau, SG, Suarez E, Timmermann BN 2000. Oleanane triterpenes from Junellia tridens. J Nat Prod 63: 1611-1614.

Cantrell CL, Franzblau SG, Fischer NH 2001. Antimycobacterial plant terpenoids. Planta Med 67: 685-694.

Copp BR 2003. Antimycobacterial natural products. Nat Prod Rep 20: 535-557.

Donald PR, Lamprecht JH, Freestone M, Albrecht CF, Bouic PJ, Kotze D, Van Jaarsveld PP 1998. A randomised placebo-controlled trial of the efficacy of betasitosterol and its glucoside as adjuvants in the treatment of pulmonary tuberculosis. Int $J$ Tuberc Lung Dis 2: 522-523.

Franzblau SG, Witzig RS, McLaughlin JC, Torres P, Madico G, Hernandez A, Degnan MT, Cook MB, Quenzer VK, Ferguson RM, Gilmam RH. 1998. Rapid, 
low-technology MIC determination with clinical Mycobacterium tuberculosis isolates by using the microplate Alamar Blue assay. J Clin Microbiol 36: 362-366.

Jimenez-Arellanes A, Meckes M, Ramirez R, Torres J, LunaHerrera J. 2003. Activity against multidrug-resistant Mycobacterium tuberculosis in Mexican plants used to treat respiratory diseases. Phytother Res 17: 903 908.

Jimenez A, Meckes M, Alvarez V, Torres J, Parra R 2005. Secondary metabolites from Chamaedora tepejilote (Palmae) are active against Mycobacterium tuberculosis. Phytother Res 19: 320-322.

Korycka-Machala M, Rumijowska-Galewicz A, Dziadek J 2005. The effect of ethambutol on mycobacterial cell wall permeability to hydrophobic compounds. Polish J Microbiol 54: 5-11.

Lall N, Meyer JJM 1999. In vitro inhibition of drug-resistant and drug-sensitive strains of Mycobacterium tuberculosis by ethnobotanically selected South African plants. J Ethnopharmacol 66: 347-354.

Newton SM, Lau C, Wright CW 2000. A review of antimycobacterial natural products. Phytother Res 14: 302-322.

Newton SM, Lau C, Gurcha SS, Besra GS, Wright CW 2002. The evaluation of forty-three plant species from in vitro antimycobacterial activities; isolation of active constituents from Psoralea corylifolia and Sanguinaria canadensis. J Ethnopharmacol 79: $57-$ 67.

Okunade AL, Elvin-Lewis MPF, Lewis WH 2004. Natural antimycobacterial metabolites: current status. Phytochemistry 65: 1017-1032.

Saludes JP, Garson MJ, Franzblau SG, Aguinaldo AM 2002. Antitubercular constituents from the hexane fraction of Morinda citrifolia Linn. (Rubiaceae). Phytother Res 16: 683-683.

Santos TC, Delle Monache F, Leitão SG 2001. Ecdysteroids from two Brazilian Vitex species. Fitoterapia 73: 215-220.

Shu YZ 1998. Recent natural products based drug development: A pharmaceutical industry perspective. J Nat Prod 61:1053-1071.

Suksamrarn A, Sommechai C 1993. Ecdysteroids from Vitex pinnata. Phytochemistry 32: 303-306.

Van Puyvelde L, Ntawukiliyayo ID, Portaels F, Hakizamungu E 1994. In-vitro inhibition of mycobacteria by Rwandese medicinal-plants. Phytother Res 8: 6569.

WHO 2000. WHO Tuberculosis Fact Sheet 2000; No. 104.

WHO 2005. Global Health Atlas, http://www.who.int/ globalatlas, accessed on July $27^{\text {th }}, 2005$.

Zhang H, Ding Y, Chen G, Dong Y, Zhu Y 1987. Active constituents of root of Euphorbia ebracteolata Hayata (Euphorbiaceae). Zhiwu Xuebao 29: 429. 431.

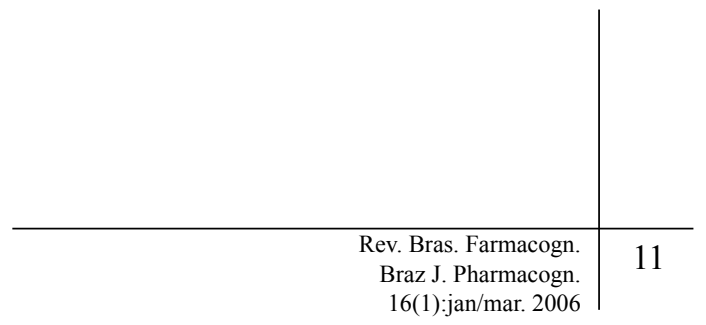

